УДК: $332.2: 332.36$

\title{
KEY ROLE OF LAND MANAGENT IN THE PLANNING OF THE DEVELOPMENT OF TERRITORIAL COMMUNITIES
}

\author{
Dorosh O.S., doctor of economics, professor, \\ National University of Life and Environmental Sciences of Ukraine, Kyiv, \\ Email:dorosholgas@ukr.net
}

Fomenko V.A., Ph.D., associate professor, Odesa State Agrarian University, Odesa, Email:fomenko@gmail.com

Melnyk D.M., postgraduate student, National University of Life and Environmental Sciences of Ukraine, Kyiv, Email:melnykdenys@gmail.com

As a result of the researches, the role of land management in the management of land and other natural resources, planning of land use systems within the territory of territorial communities is estimated. The significant problems in this process are revealed, the reasons for their occurrence, which are the result of ineffective system of public administration that is poorly adapted to decentralization processes in the field of land relations, are presented. In this regard, proposals have been formulated regarding their solution (legislative, institutional and organizational), and the expected results are presented in case of their implementation.

Key words: land management, territorial community, forecast-planning documentation, management of land and other natural resources, land use systems, development of territories

Formulation of the problem. In April 2014, the implementation of the decentralization reform in Ukraine was launched. Approved Concept of reforming local self-government and territorial organization of power in Ukraine and approved Action Plan for its Implementation. In accordance with the Law of Ukraine "On Voluntary Association of Territorial Communities" and the Methodology for the 
formation of sustainable territorial communities, the main direction of decentralization is defined - the creation of voluntary associations of territorial communities. Despite a number of adopted legislative and regulatory documents, there are complexities associated with the creation and development of united territorial communities (hereinafter - UTC) and the formation of land use systems in these communities in Ukraine. This, above all, is the result of an ineffective system of public administration that is poorly adapted to decentralization processes in the field of land relations. Disorderly in planning of the development of the land use system, and the management of land in the UTC, the lack of mechanisms for their implementation leads to the adoption of ineffective management decisions regarding the rationalization of land use in the community and violations of environmental safety. In this context, the direct involvement of the community in management of land and other natural resources, planning the development of a land use system within its territory, under the current decentralization processes, becomes of particular importance.

Analysis of recent research and publications. A detailed overview of the theoretical approaches in the direction of state management of the development of territorial communities was developed by V. Kuibida, S. Sakhanenko, Y. Sharov and other scholars. Interesting theoretical and practical developments concerning the institutionalization of land and other natural resources management are inherent in the scientific work of I. Bystriakov, V. Budziak, I. Dorosh, A. Tretiak. However, the land management planing aspect in management of land and other natural resources and planning the development of a land use system within the territories of communities in the conditions of decentralization of power in Ukraine is not sufficiently explored.

The purpose of the study is to justify the role of land management planing in management of land and other natural resources, planning the development of a land use system within the community within the current transformational processes related to the reform of local self-government in Ukraine. 
Presenting main material. As of April 2018, 728 UTCs were created on the territory of Ukraine, in which 6.3 million people live [4]. Each newly formed community must have its own development priorities and its own system of values regarding the management of land-resource potential within its territory.

However, these communities suffer a lot of complexities associated with the management of land and other natural resources, planning of the development of land use systems within the territorial legal personality. Their development is hampered by problems that require immediate resolution, which include: 1) the lack of information on land and other natural resources in the territory of the UTC; 2) the absence of forecast-planning documentation on the territory of the UTC; 3) no boundaries of UTCs and settlements are established; 4) unregulated use of land melioration systems at the local level; 5) unregulated use of field-protecting forest belts that are not in use by forest enterprises; 6) unsatisfactory condition of the objects of the nature reserve fund, recreational, historical and cultural purposes, deterioration of the ecological situation in the land use system within the territories of the communities; 7) lack of revenues to the local budget from rent for land and other natural resources.

UTCs are deprived of the opportunity to make managerial decisions because they lack information on the rights to land and other natural resources, their potential, the state of use and protection. Information on geospatial data is not available because it is distinguished between branch offices. As a consequence, community awareness of existing environmental, economic and social problems is practically zero. Therefore, they are not able to answer the question: Where do you need to direct resources, where there is potential for development?

Full provision of information to UTC is possible in the case of the creation of a unified national infrastructure of geospatial data of Ukraine, which would combine spatial, statistical and administrative data on all natural resources in related industries, online access to them and the creation of electronic information services [3, p. 38]. This information can be used by all if necessary: society, investor, business structures, specialists, project organizations, state and local authorities, UTCs and citizens. 
Determination of the perspective organization of the use and protection of land and other natural resources within the territory of the UTC, becomes a priority, since the introduction of decentralization processes has brought a new object of land management - united territorial communities. To some extent, at the legislative level, there are attempts to resolve issues related to the development of city-planning documentation (the procedure for developing plans of UTCs, the establishment of rules of construction, etc.). But this documentation does not solve the problems of organizing the rational use and protection of land and other natural resources. Therefore, planning activities related to the use of agricultural land, forest, water resources, environmental protection, recreational and health purpose should be based on land management documentation (through the development of schemes or land management projects), which is currently not being developed for the territory of the UTC.

A significant obstacle to the economic development of UTCs is the absence of borders between these communities and settlements. Currently, it is impossible to establish the borders of UTC, since they are not recognized by the subject of the administrative-territorial system under the Constitution of Ukraine. The existing boundaries of the settlements of the community do not correspond to legally established borders, since residential and public construction now in most cases went beyond the boundaries of settlements. The documentation defining the boundaries of the village councils in the UTC is the technical documentation for the inventory, made in 1991-1992 using outdated cartographic materials even at that time [6]. The absence of borders not only significantly complicates the activities of local selfgovernment bodies, but also leads to violation of the provisions of land legislation at the disposal of land, reducing the money receipts to local budgets. This leads to conflict situations, which is reflected on the effectiveness of land use within communities.

In order to overcome these problems, it is necessary: 1) to amend the Law of Ukraine "On Land Management" by introducing the development of a "land management project on the definition, establishment of boundaries of the territory of 
the UTC"; 2) to regulate at the legislative level that the ground for the establishment (change) of the boundaries of the settlement should be the plan of the land-economic structure (spatial plan of the territory development), rather than the general plan of the settlement; 3 ) to simplify the procedure for establishing and changing boundaries of settlements in the territory of the united community; 4) to develop a plan of councils within the territory of the UTC.

Particularly we should pay attention to the characteristics of meliorated land located within the territory of the UTC. The unregulated use of meliorative systems is coused, first of all, by the lack of monitoring of the state of melioration objects at the local level. In addition, farm drainage channels withdrawn from the balance of inter-district water management, were not transferred to the UTC due to the lack of their authority to dispose of land outside the settlements. As a consequence, communities are deprived of the opportunity to serve melioration facilities. Therefore, it is necessary to regulate at the legislative level: 1) the transfer of land melioration systems of local importance to community management; 2) to develop schemes of land melioration on the territory of united territorial communities, which should be melioration channels, engineering structures, boundaries of service strips [6].

It is equally important to regulate issues related to the use of fieldprotective forest bands that are not in use by forest enterprises in the territory of the UTC. However, the community can not significantly influence the solution of this problem, since it does not have authority over the disposal of land outside settlements, and there is no information regarding available areas under non-use forestry parks.

In this connection, it is necessary to form land plots of communal ownership within and outside the settlements of the UTC and to register the right of communal property to them. Such a procedure is the basis for the development of land use documentation with the definition of the further use of field-protective forest bands.

Within the territories of communities in unsatisfactory condition there are objects of the natural reserve fund, recreational, historical and cultural purposes. 
The reason is that the community is prevented from solving these problems, and thus violates the basic principle of the ubiquity of local self-government. In this context, it is advisable to regulate, at the legislative level, an agreement with land owners to preserve natural and cultural objects.

Problems related to the deterioration of the ecological situation in the land use system within the territory of the UTC remain unresolved. The main processes and environmental risks that can negatively affect the potential of land and other natural resources include [1, p.182]: non-compliance with ecologically permissible proportions of arable land, forest plantations, natural forage lands, etc.; excessive amounts of agricultural land cultivation, which deepens the natural processes of soil formation; uncontrolled use of chemicals (pesticides, nitrates); increase in the influence of biological components (radionuclides, heavy metals, infectious agents); deterioration of the functioning of natural ecosystems through the use of intensive land use technologies; development of degradation processes (reduction of humus fraction in soils due to the replacement of natural plants with agricultural crops); the spread of erosion processes exceeds the rate of formation and reproduction of soils; the processes of clogging and contamination of land with unauthorized dumps and industrial waste have intensified.

In order to prevent the increase of ecological danger in the land use system, national legislation should contain state standards, norms, and rules for the prevention of socio-ecological, biosphere-ecological and resource-ecological hazards. In addition, there is a need to develop a mechanism for sanitary cleaning of the territory by developing a waste management program and a scheme for sanitation of the community. It is important to establish educational work among the inhabitants of these communities regarding the need for sorting garbage.

In addition to the ecological risks associated with the development of land use systems in UTC, economic take on a major role, namely non-payment of revenues to the local budget from fees for land and other natural resources. The list of reasons, which unjustifiably complicated the development of communities, is proposed: 1) 
restriction of "land" jurisdiction of local self-government bodies only outside the settlements and the formation of land plots of communal property within and outside settlements; 2) lease at a low rental rate for 49 years a significant amount of land reserves, which makes it impossible to develop and expand the settlements of communities; 3) the establishment of lease rates for the use of agricultural land without taking into account the needs of communities, or land used without paying taxes; 4) the lack of information on taxpayers in the fiscal authorities (also due to the constant reformation and imperfection of the State Land Cadastre, lack of complete information on land plots, information on the status and owners of most land is not fixed), which leads to raider attacks, abuses and corruption in the land use system in the community.

In this context, we must introduce, as part of the UTC, state registers of real rights to real estate and their encumbrances and land registers. To resolve these problems, it is necessary to consolidate the procedure for the prosecution of officials of local self-government bodies and state authorities of local authorities for the illegal alienation or ineffective use of communal property objects at the legislative level.

The study of urgent problems, the establishment of the reasons for their emergence in the chosen direction of research, allowed to formulate proposals for their solution and provides the expected results in the event of their introduction (Table 1). 


\begin{tabular}{|c|c|c|c|}
\hline Problem & Reasons of the problem & Problem solving proposals & Expected results \\
\hline $\begin{array}{l}\text { Lack of information } \\
\text { on land and other } \\
\text { natural resources in } \\
\text { the community }\end{array}$ & $\begin{array}{l}\text { - almost complete absence of } \\
\text { information on rights on land and other } \\
\text { natural resources, their potential, state of } \\
\text { use and protection in the territorial } \\
\text { communities; } \\
\text { - differentiation of information from } \\
\text { geospatial data in different departments; }\end{array}$ & $\begin{array}{l}\text { to regulate at the legislative level the } \\
\text { transfer of powers to communities regarding } \\
\text { the disposal of land within communities; } \\
\text { - to legalize the transfer of communal } \\
\text { ownership of land owned by the territorial } \\
\text { communities located outside the settlements } \\
\text { (except those where the state-owned objects } \\
\text { are located); } \\
\text { - to create a unified national geospatial } \\
\text { data infrastructure (hereinafter - NGDI) of } \\
\text { Ukraine for integration of spatial, statistical } \\
\text { and administrative data, online access to them } \\
\text { and creation of electronic information services; }\end{array}$ & $\begin{array}{l}\text { the introduction of NGDI } \\
\text { will allow communities to manage } \\
\text { assets more effectively, which will } \\
\text { reduce their spending from the } \\
\text { budget, attract investment, allow } \\
\text { for all types of analysis to justify } \\
\text { the community's economic } \\
\text { development, the provision of vital } \\
\text { services and the development of } \\
\text { the geospatial world; } \\
\text { information will be } \\
\text { available to investors, } \\
\text { professionals, design organizations } \\
\text { and interested government bodies, } \\
\text { organizations and citizens; }\end{array}$ \\
\hline $\begin{array}{l}\text { Lack of forecast- } \\
\text { planning } \\
\text { documentation on the } \\
\text { territory of the united } \\
\text { territorial community }\end{array}$ & $\begin{array}{l}\text { - lack of a well-balanced state policy } \\
\text { regarding planning of land use } \\
\text { development in territorial communities, } \\
\text { mechanisms for their implementation; } \\
\text { - imperfection of legislative acts and } \\
\text { subordinate normative documents in the } \\
\text { field of land management; } \\
\text { - differentiation of information in a } \\
\text { number of departmental organizations, for } \\
\text { which it is often required to pay significant } \\
\text { amounts; } \\
\text { - the work performed is overloaded } \\
\text { with official approvals and approvals of }\end{array}$ & $\begin{array}{l}\text { - program on the use and protection of } \\
\text { land and other natural resources in the } \\
\text { community; } \\
\text { - schemes of land management and } \\
\text { feasibility studies on the use and protection of } \\
\text { land in the community; } \\
\text { - scheme of spatial development of land } \\
\text { use system of engineering infrastructure in the } \\
\text { community; } \\
\text { - development plan (zoning of lands by } \\
\text { their categories and types) of land use within } \\
\text { the territory of the community; } \\
\text { - scheme of existing territorial restrictions }\end{array}$ & $\begin{array}{l}\text { - the development and } \\
\text { implementation of the listed } \\
\text { planning land use documentation } \\
\text { will ensure: 1) in the economic } \\
\text { sphere - an increase in the } \\
\text { financial capacity of the } \\
\text { communities; 2) in the ecological } \\
- \text { optimized measures for the } \\
\text { protection of land; 3) in the social } \\
\text { sphere - creation of conditions for } \\
\text { a healthy living environment; }\end{array}$ \\
\hline
\end{tabular}




\begin{tabular}{|c|c|c|c|}
\hline & $\begin{array}{l}\text { numerous departments; } \\
\text { - } \quad \text { corruption component; }\end{array}$ & $\begin{array}{l}\text { (encumbrances) for using land in the } \\
\text { community; } \\
\text { - plan of spatial development of land use } \\
\text { cystem in the territory of a territorial } \\
\text { community; } \\
\text { - plan of the boundaries of the } \\
\text { administrative-territorial division of councils } \\
\text { that are part of the territory of the united } \\
\text { territorial community; }\end{array}$ & \\
\hline $\begin{array}{l}\text { Not established } \\
\text { boundaries of UTCs } \\
\text { and settlements }\end{array}$ & $\begin{array}{l}\text { the constitution of Ukraine does } \\
\text { not establish territorial communities as } \\
\text { a subject of administrative-territorial } \\
\text { organization; } \\
\text { inconsistency of the existing } \\
\text { boundaries of settlements that are part } \\
\text { of the community legally established; } \\
\text { - the boundaries of village } \\
\text { councils within the community are } \\
\text { determined on the basis of outdated } \\
\text { technical documentation on land } \\
\text { inventory; } \\
\text { most lack of funds in the budgets of } \\
\text { - an impressive number of } \\
\text { approvals when performing work; }\end{array}$ & $\begin{array}{l}\text { implement the development of the Land } \\
\text { Management Project on the definition and } \\
\text { establishment of the boundaries of the } \\
\text { community (to amend the Law of Ukraine "On } \\
\text { Land Management"); } \\
\text { - to regulate at the legislative level that } \\
\text { the ground for the establishment (change) of } \\
\text { the boundaries of the settlement should be the } \\
\text { plan of land-economic arrangement (spatial } \\
\text { plan of the territory development), rather than } \\
\text { the master plan of the settlement; } \\
\text { - simplify the procedure for establishing } \\
\text { (changing) the boundaries of settlements in the } \\
\text { community; } \\
\text { of develop a plan of councils that are part } \\
\text { of a territorial community; }\end{array}$ & $\begin{array}{l}\text { - ensure the lawfulness of the } \\
\text { local self-government body's } \\
\text { activity within the specified limits; } \\
\text { - promote economic } \\
\text { development of communities } \\
\text { taking into account the interests of } \\
\text { its inhabitants; } \\
\text { - improve control over the } \\
\text { use and protection of land, more } \\
\text { efficient use of communal land; } \\
\text { - reduce the number of land } \\
\text { disputes; }\end{array}$ \\
\hline $\begin{array}{l}\text { Unregulated use of } \\
\text { land melioration } \\
\text { systems at the local } \\
\text { level }\end{array}$ & $\begin{array}{l}\text { monitoring of the state of } \\
\text { melioration objects is not carried out; } \\
\text { - farm drainage channels } \\
\text { withdrawn from the balance between } \\
\text { inter-district water management } \\
\text { departments are not transferred to } \\
\text { communities due to lack of authority } \\
\text { over the disposal of land outside the } \\
\text { settlements; }\end{array}$ & $\begin{array}{l}\text { to regulate, at the legislative level, } \\
\text { the transfer of land melioration systems of } \\
\text { local importance to community } \\
\text { management; } \\
\text { reclamation on the territory of united } \\
\text { territorial communities, which should be } \\
\text { melioration channels, engineering } \\
\text { structures, boundaries of service strips }\end{array}$ & $\begin{array}{l}\text { - improve the efficiency of } \\
\text { agricultural land use; } \\
\text { characteristics of soils; }\end{array}$ \\
\hline
\end{tabular}




\begin{tabular}{|c|c|c|c|}
\hline $\begin{array}{l}\text { Unregulated use of } \\
\text { field-protecting forest } \\
\text { belts that are not in } \\
\text { use by forest } \\
\text { enterprises }\end{array}$ & $\begin{array}{l}\text { lack of authority to dispose of land } \\
\text { outside settlements; } \\
\text { "landless" forest-protected forest bands; } \\
\text { the care of field-protected forest belts; }\end{array}$ & $\begin{array}{l}\text { on the basis of registration of the right } \\
\text { of communal ownership to land plots and } \\
\text { making a decision on their further use through } \\
\text { the development of appropriate documentation } \\
\text { on the use of field protection forest belts; } \\
\text { to conclude a lease agreement between } \\
\text { the community and the tenant of agricultural } \\
\text { land for the taking of field protection forest } \\
\text { belts for temporary use and ensure their proper } \\
\text { care; }\end{array}$ & $\begin{array}{l}\text { improve the environmental } \\
\text { condition and qualitative soil } \\
\text { characteristics; } \\
\text { - increase crop yields; }\end{array}$ \\
\hline $\begin{array}{l}\text { The unsatisfactory } \\
\text { condition of objects of } \\
\text { the nature reserve } \\
\text { fund, recreation, } \\
\text { recreational, historical } \\
\text { and cultural purposes } \\
\text { within the territories of } \\
\text { communities }\end{array}$ & $\begin{array}{l}\text { lack of community influence in } \\
\text { solving these problems; }\end{array}$ & $\begin{array}{l}\text { - To legitimize the community's } \\
\text { responsibility for the conservation of real estate } \\
\text { (state value, NPF, etc.) } \\
\text { - make agreements with land owners to } \\
\text { preserve natural or cultural objects; }\end{array}$ & $\begin{array}{l}\text { - the state of the objects of } \\
\text { the nature reserve fund, } \\
\text { recreational and historical-cultural } \\
\text { purpouse will improve; }\end{array}$ \\
\hline $\begin{array}{l}\text { The deterioration of } \\
\text { the ecological } \\
\text { situation in the } \\
\text { system of land use of } \\
\text { community territories }\end{array}$ & $\begin{array}{l}\text { - environmental risks include: } \\
\text { - there is no balance between } \\
\text { natural lands and lands affected by } \\
\text { anthropogenic influence; } \\
\text { - excessive amounts of arable land } \\
\text { and introduction of intensive land use } \\
\text { technologies deepen destructive } \\
\text { processes in soils and degradation of } \\
\text { land; } \\
\text { - uncontrolled use of chemicals; } \\
\text { biological components; } \\
\text { - the processes of littering and } \\
\text { contamination of land with } \\
\text { unauthorized landfills and industrial } \\
\text { waste have intensified; }\end{array}$ & $\begin{array}{l}\text { national legislation should be filled } \\
\text { in with state standards, guidelines, norms } \\
\text { and rules for the prevention of socio- } \\
\text { ecological, biosphere-ecological and } \\
\text { resource-ecological hazards; } \\
\text { - develop a waste management } \\
\text { program and a scheme for sanitary cleaning } \\
\text { of the community; } \\
\text { a to establish the educational work } \\
\text { among the population regarding the need } \\
\text { for sorting of garbage; }\end{array}$ & $\begin{array}{l}\text { - provide ecological safety } \\
\text { of life of inhabitants of } \\
\text { territorial communities; } \\
\text { - increase the investment } \\
\text { attractiveness of the territory for } \\
\text { agriculture and increase the } \\
\text { efficiency of agricultural } \\
\text { production; } \\
\text { - increase revenues to the } \\
\text { budget; }\end{array}$ \\
\hline
\end{tabular}




\begin{tabular}{|c|c|c|c|}
\hline & $\begin{array}{l}\text { - absence of a solid domestic } \\
\text { waste landfill; }\end{array}$ & & \\
\hline $\begin{array}{l}\text { Lack of revenues to } \\
\text { the local budget from } \\
\text { land tax payment }\end{array}$ & $\begin{array}{l}\text { land plots of communal ownership } \\
\text { within and outside settlements are not } \\
\text { formed; } \\
\text { of limitation of the "land" jurisdiction } \\
\text { within the boundaries of settlements; } \\
\text { renting low-rented rates for } 49 \\
\text { years of significant amount of land } \\
\text { reserves; } \\
\text { agricultural land were set without taking } \\
\text { into account the needs of communities, or } \\
\text { land was used without paying taxes; } \\
\text { - alienation of communal and private } \\
\text { agricultural lands at low prices; } \\
\text { - lack of information on taxpayers in } \\
\text { fiscal authorities; } \\
\text { - constant reformation and } \\
\text { imperfection of the State Land Cadastre; }\end{array}$ & $\begin{array}{l}\text { united territorial communities should be } \\
\text { registered as legal entities that have legal } \\
\text { personality to acquire ownership status; } \\
\text { introduce a communal-rent model for } \\
\text { the use of natural assets; } \\
\text { justice responsibility for the illegal alienation } \\
\text { or ineffective use of communal property } \\
\text { objects; } \\
\text { rights introduce a state registrar of the real } \\
\text { land as an employee of communities; }\end{array}$ & $\begin{array}{l}\text { the acquisition of a legal } \\
\text { entity status by a territorial } \\
\text { community will ensure their } \\
\text { economic self-sufficiency (due to } \\
\text { the transfer of ownership to the } \\
\text { communities, primarily land, } \\
\text { enterprises, technologies through } \\
\text { which the material basis for their } \\
\text { development was formed); } \\
\text { - increasing the number of } \\
\text { objects of taxation, leased land } \\
\text { will contribute to filling the local } \\
\text { budgets; } \\
\text { - will allow citizens of the } \\
\text { community to retreive needed } \\
\text { information from relevant registers } \\
\text { directly in the community. }\end{array}$ \\
\hline
\end{tabular}

Розроблено з використанням джерел [1 - 3, 5 - 7] 
CONCLUSIONS. As a result, we note that most of the problematic issues related to the management of land and other natural resources, the planning of land use within community territories is the result of an ineffective system of public administration that is poorly adapted to decentralization processes in the field of land relations and underestimating the role of land management as a key the regulatory tool in this process. In this regard, we offer:

- to create a unified national geospatial data infrastructure (NGDI), which would combine spatial, statistical and administrative data on all natural resources in relevant industries, online access to them and creation of electronic information services;

- introduce into practice of land management activities the development of the following types of forecast-planning documentation: 1) Program of use and protection of land and other natural resources in the community; 2) Scheme of land management and feasibility study on the use and protection of land on the territory of the community; 3) Scheme of spatial development of the land use system of engineering infrastructure on the territory of the community; 4) Plan of spatial development of the land use system on the territory of the community; 5) Waste management program and sanitary clearing scheme of the community.

- to settle at the legislative level that the ground for the establishment (change) of the boundaries of the settlement should be the plan of the land-economic structure (spatial plan of the territory development), rather than the general plan of the settlement;

- to legalize the transfer of land reclamation systems of local importance to community management and to develop schemes for land reclamation in the territory of the UTC, indicating reclamation channels, engineering structures, and the boundaries of service strips;

- to form land plots of communal ownership within and outside the settlements of the UTC and to register the right of communal property to them, which will also be the basis for the development of documentation defining the further use of fieldprotective forest belts that are not in use by forest enterprises in the territory of UTC; 
- to develop state standards, norms and rules for the prevention of socioecological, biosphere-ecological and resource-ecological hazards in the system of land use of community territories;

- to introduce a utility model for the use of natural assets within the territory of the UTC to ensure their self-sufficiency.

\section{References}

1. Budziak O. (2016), „Formation of ecologically safe land use on agricultural lands of Ukraine“, Zbalansovane pryrodokorystuvannia, no. 3 pp.180187 ;

2. Dorosh O. (2015), „Organizational and institutional support of territorial planning of land use of rural territories “, Ekonomist, no. 8 pp. 22-25;

3. O. Dyshlyk, A. Dorosh, A. Tarnopolsky, Ye. Tarnopolsky (2018), "Infrastructure of geospatial data in Ukraine: status and methodological problems of legislative regulation", Land management, cadastre and land monitoring, no. 1 pp. 33-43;

4. Monitoring of the power decentralization process and reformation of local self-government, Available at: http://decentralization.gov.ua/uploads/library/file/247/Моніторинг_Дец.ентраліз ація_10.04.2018 1_.pdf (last viewed 28.07.2018);

5. The Law of Ukraine "On Land Management" 2003. Kyiv, Vidomosti Verkhovhoi Rady Ukrainy;

6. Samoilova I. Melnyk D. (2017), „Areas of strengthening the influence of territorial communities in the system of land resources management", Zbalansovane pryrodokorystuvannia, no. 4. pp. 12-17;

7. Tretiak A., Tretiak V., Priadka T., Tretiak N. (2017), „Territorial planning of land use in the context of the formation of financial stability of the combined territorial communities", Land management, cadastre and land monitoring, no. 1. pp. 21-27. 
КЛЮЧОВА РОЛЬ ЗЕМЛЕУСТРОЮ У ПЛАНУВАННІ РОЗВИТКУ СИСТЕМИ ЗЕМЛЕКОРИСТУВАНЬ У МЕЖАХ ТЕРИТОРІАЛЬНИХ ГРОМАД

В результаті досліджень оцінена роль землеустрою в управлінні земельними та іншими природними ресурсами, плануванні системи землекористувань у межах території територіальних громад. Виявлено суттєві проблеми у изьому процесі, наведено причини їх виникнення, щзо є наслідком неефективної системи державного управління, яка слабо адаптована до здійснення децентралізаційних процесів у сфері земельних відносин. У изьому зв'язку сформовано пропозиції стосовно їх вирімення (законодавчого, інституиійного та організаційного спрямування) та наведено очікувані результати в разі їх запровадження.

Ключові слова: землеустрій, територіальна громада, прогнозно-планувальна документація, управління земельними та іншими природними ресурсами, система землекористувань, розвиток територій

$* * *$

Дорош О.С., Фоменко В.А, Мельник Д.Н.

КЛЮЧЕВАЯ РОЛЬ ЗЕМЛЕУСТРОЙСТВА В ПЛАНИРОВАНИИ РАЗВИТИЯ СИСТЕМЫ ЗЕМЛЕПОЛЬЗОВАНИЯ В ПРЕДЕЛАХ ТЕРРИТОРИАЛЬНЫХ ОБЩИН

В результате исследований оценена роль землеустройства в управлении земельными и другими природными ресурсами, планировании системы землепользования в пределах территории территориальных общин. Выявлены существенные проблемы в этом процессе, приведены причины их возникновения, что является следствием неэффективной системы государственного управления, слабо адаптированной $к$ осуществлению децентрализационных проиессов в сфере земельных отношений. В этой связи есть предложения относительно их решения (законодательного, институционального $u$ организационного направления) и приведены ожидаемые результаты в случае их введения.

Ключевые слова: землеустройство, территориальная община, прогнознопланировочная документация, управление земельными и другими природными ресурсами, система землепользования, развитие территорий. 